\title{
THE POSITIVES AND THE NEGATIVES OF TEACHERS' EVALUATION FROM THE POINT OF VIEW OF EVALUATORS AND THE EVALUATED
}

\section{[POZITIVA A NEGATIVA EVALUACIE UCITELOV Z ASPEKTU HODNOTENYCH I HODNOTIACICH]}

\author{
Daniela Muglova - Eva Mala
}

\section{doi: 10.18355/PG.2017.6.1.3}

\begin{abstract}
The intention of the paper is a multi-aspectual analysis of evaluation of teachers' competence profile. The main formal indicators (who evaluates, what and how often is evaluated) are summarized on the basis of questionnaires. The interpretation of the positives and the negatives of teachers' evaluation from the point of view of teachers and their headmasters is presented. The four evaluation perspectives are discussed within the analysis of evaluation of teachers' competences: (1) obligatory, direct; (2) institutional, indirect; (3) optional; (4) individual, self-reflexive.
\end{abstract}

\section{Key words}

Evaluation, teachers, competences, questionnaire

\section{Anotácia}

Intenciou príspevku je viacaspektová analýza hodnotenia kompetenčného profilu učitel’ov. Na základe dotazníkového prieskumu sú zosumarizované základné formálne ukazovatele (kto hodnotí, čo hodnotí a ako často hodnotí ) a je prezentovaný pokus o interpretáciu pozitív a negatív hodnotenia učitel'ov z pohl'adu samotných učitel'ov a ich nadriadených. V rámci analýzy hodnotenia kompetencií učitel'ov sú predložené štyri hodnotiace perspektívy: (1) obligatórna, priama; (2) inštitucionálna, nepriama; (3) fakultatívna; (4) individuálna, sebareflexívna.

\section{Kl’účové slová}

Hodnotenie, učitelia, kompetencie, dotazník

\section{Úvod}

Problematika špecifikácie hodnotiacich kritérií učitel'ov nie je v odbornej pedagogickej literatúre novum. Potreba objektívneho, holistického pohl'adu na kompetenčný profil pedagóga v klúčových pôsobnostiach vo všetkých základných oblastiach (edukatívny vplyv na žiaka, efektívnost' vyučovacieho procesu, vlastný profesijný rozvoj) je stále aktuálna. Doteraz však neexistuje taký systém hodnotenia, ktorý by zohl'adňoval všetky faktory, ovplyvňujúce prácu učitel’a a súčasne zaručil čo najväčšiu mieru objektivity. Práve tento fakt bol iniciačným momentom pre návrh projektu s názvom Hodnotenie kompetencii učitel'a, ktorý bol v júli 2015 schválený Agentúrou pre vedu a výskum MŠVVaŠ SR (APVV-14-0446). V úvodnej fáze riešenia projektu sme uskutočnili rozsiahly dotazníkový prieskum, zameraný na rôzne aspekty hodnotenia učitel'ov, adresovaný učitel'om 1. a 2. stupňa základných škôl a všetkých typov stredných škôl (podl'a ISCED 1, 2, 3 a 3C). Distribúciu dotazníka sme realizovali v dvoch rovinách: oslovili sme hodnotitel'ov (riaditel'ov škôl) a identické 
otázky, avšak s malými modifikáciami, sme adresovali hodnoteným (učitel’om). Celková návratnost' dotazníka bola 145 respondentov z radov vedenia škôl a 670 z radov učitel'ov, čo jednoznačne poskytuje validnú vzorku pre isté zovšeobecnenia. (Bližšie pozri: L. Magová a kol., 2016/244 et passim.)

\section{Analýza hodnotenia učitel'ov}

Intenciou predmetného príspevku je viacaspektová analýza hodnotenia ako nástroja na posúdenie kompetenčného profilu učitel’ov. Predmetom nášho záujmu však nebude vytvorenie nových či hodnotenie už existujúcich evaluačných kritérií, ale pohl'ad na vybrané aspekty hodnotenia v rámci analýzy SWOT. Základné formálne ukazovatele (kto hodnotí a ako často hodnotí ), ktoré evaluáciu inherujú, zosumarizujeme a pokúsime sa interpretovat' pozitíva a negatíva hodnotenia $\mathrm{z}$ aspektu učitel'ov i riaditel'ov škôl.

Prvou rovinou sú hodnotiace perspektívy, ktoré sme rozdelili z hl’adiska ich štruktúry na: 1.obligatórnu, priamu, t. j. inštitucionálnu, legislatívne zakotvenú povinnost' hodnotit' učitel'a, resp. riaditel'a; 2. inštitucionálnu nepriamu povinnost' bez explicitného uvedenia v dikcii zákona; 3. fakultatívne možnosti hodnotenia; a do štvrtej, samostatnej kategórie sme vyčlenili individuálne, sebareflexívne hodnotenia samotného učitel'a. Pri inštitucionálnom hodnotení sme hodnotitel'ov rozdelili na a) interných a b) externých. Toto vnútorné rozdelenie považujeme za nevyhnutné práve z hl'adiska objektivity hodnotiacich perspektív.

\section{Obligatórne priame inštitucionálne hodnotenie}

\section{a) interné}

Tento druh hodnotenia je legislatívne zakotvený a vyplýva zo zákona č. 317/2009 o pedagogických zamestnancoch a odborných zamestnancoch. V ňom sa spravidla určuje aj minimálna frekvencia kontroly a povinnost' oboznámit' hodnoteného s jeho výsledkom. Hodnotenie učitel'ov sa realizuje internými vnútroškolskými mechanizmami, prostredníctvom členov školského manažmentu, resp. poverených členov pedagogického zboru. Internú evaluáciu vykonáva:

- uvádzajúci pedagogický zamestnanec, ktorý hodnotí začínajúceho pedagogického zamestnanca, a to priebežne;

- uvádzajúci odborný zamestnanec, ktorý hodnotí začínajúceho odborného zamestnanca priebežne a na konci adaptačného obdobia,

- priamy nadriadený (riaditel' školy) podriadeného jedenkrát ročne najneskôr do konca školského roka.

Ked’že ide o hodnotenia regulované legislatívne, hodnotitel'om vyplýva zo zákona koho a ako často majú hodnotit'. Už pri záväznej povinnosti hodnotit' podriadeného, narážame na istú disproporciu medzi želaným stavom a realitou. $\mathrm{V}$ našom dotazníkovom prieskume totiž 91 učitel'ov (15\%) uvádza, že ich riaditel' školy nehodnotí vôbec a 53 respondentov (8\%) sa vyjadrilo, že ich hodnotí menej ako raz za rok. Zaujímavý je údaj z dotazníka riaditel'ov škôl, kde ani jeden respondent neuvádza, že by svojich učitel'ov nehodnotil vôbec. V záujme objektivity však na porovnanie uvádzame aj frekvenciu hodnotenia iným členom vedenia školy, pretože riaditel' má legitímnu možnost' delegovat' svoju povinnost', napr. na zástupcu riaditel'a školy, pedagogického zamestnanca špecialistu, resp. zástupcu poradných orgánov školy. Túto alternatívu pripúšt’a až $70 \%$ riaditel'ov. Absolútna väčšina riaditel'ov poveruje touto úlohou svojho zástupcu. Takmer polovica respondentov $\mathrm{z}$ radov učitel'ov uvádza, že ich zástupca riaditel'a hodnotí viackrát za rok (45\%) a len $15 \%$ nebolo zástupcom riaditel'a vôbec hodnotených. V doplňujúcich komentároch k vybraným položkám dotazníka sa riaditelia prihovárajú za to, aby hodnotiace 
kompetencie zo zákona prešli na ich zástupcov. Zriedkavejšie poveruje riaditel' hodnotením aj predsedu predmetovej komisie (PK). Štatisticky z nášho anketového prieskumu z radov učitel'ov vyplýva, že tento hodnotitel' najčastejšie hodnotí viackrát za rok. Uvádza to 202 učitel'ov, t. j. 30\%.

Sporadicky hodnotenie realizujú aj iní hodnotitelia. Respondenti uvádzajú, že niekedy riaditel' prenecháva hodnotenie vedúcemu metodického združenia alebo predsedovi Rady školy. Pre prehl'adnost' uvádzame údaje o frekvencii interného hodnotenia $\mathrm{z}$ anketového prieskumu v tabul'ke 1. (Percentá sú zaokrúhlené na celé čísla.)

Tab. 1 Frekvencia interného hodnotenia

\begin{tabular}{|l|l|l|l|l|}
\hline FREKVENCIA / & vôbec nie & $\begin{array}{l}\text { menej ako } \\
\text { raz za rok }\end{array}$ & raz za rok & $\begin{array}{l}\text { viackrát ako } \\
\text { raz za rok }\end{array}$ \\
\hline riaditel & $97(14 \%)$ & $53(8 \%)$ & $263(39 \%)$ & $257(38 \%)$ \\
\hline zástupca riaditel'a & $103(15 \%)$ & $31(5 \%)$ & $233(35 \%)$ & $303(45 \%)$ \\
\hline predseda PK & $277(41 \%)$ & $44(7 \%)$ & $147(22 \%)$ & $146(22 \%)$ \\
\hline
\end{tabular}

Z hl'adiska spätnej väzby uvádza 137 riaditel’ov (95\%), že hodnoteného vždy oboznamuje s výsledkom hodnotenia, len $7(5 \%)$ riaditel'ov uviedlo, že učitel'ov oboznamuje s hodnotením iba niekedy a 1 riaditel' (1\%) uvádza, že nedáva hodnotenému spätnú väzbu. Konkrétne údaje o oboznamovaní učitel’ov s výsledkami evaluácie uvádzame v tabul'ke 2.

Tab. 2 Frekvencia oboznamovania s výsledkom hodnotenia

\begin{tabular}{|l|l|l|l|}
\hline $\begin{array}{l}\text { OBOZNÁMENIE } \\
\text { S VÝSLEDKOM } \\
\text { HODNOTENIA / } \\
\text { HODNOTITEL }\end{array}$ & vždy & niekedy & nikdy \\
\hline riaditel & $137(94 \%)$ & $7(5 \%)$ & $1(1 \%)$ \\
\hline zástupca & $513(77 \%)$ & $54(8 \%)$ & $103(15 \%)$ \\
\hline predseda MK & $330(49 \%)$ & $66(10 \%)$ & $274(50 \%)$ \\
\hline
\end{tabular}

b) externé

Externými mimoškolskými hodnotitel'mi sú orgány štátnej správy, predovšetkým inštitút školskej inšpekcie. Externé hodnotenie zo strany školskej inšpekcie je riadené Zákonom o štátnej správe v školstve a školskej samospráve č. 596/2003, kde sa v §13 O úlohe štátnej správy uvádza, že inšpekciu (včítane hodnotenia učitel'ov jednotlivých predmetov) vykonáva Štátna školská správa prostredníctvom školských inšpektorov, 
ktorých touto úlohou poveruje hlavný školský inšpektor alebo riaditel' školského inšpekčného centra. V predmetoch náboženstvo a náboženská výchova ich navyše poveruje aj osoba príslušnej cirkvi alebo náboženskej spoločnosti. Podrobnosti o organizácii školskej inšpekcie a postupoch pri jej vykonávaní upravuje vyhláška Ministerstva školstva SR z 31.3.2005. Podl'a § 3 odseku 5 a § 37 odseku 2 zákona 596/2003 sa inšpekcia v školách a školských zariadeniach vykonáva spravidla raz za pät' rokov. V zákone figuruje aj povinnost' informovat' priameho nadriadeného (riaditel'a školy) o termíne, účele a záveroch inšpekcie. Č́selné a percentuálne vyjadrenia hodnotitel'ov $\mathrm{z}$ radov školských inšpektorov $\mathrm{z}$ hl'adiska frekvencie hodnotenia a spätnej väzby sú prezentované v tabul'kách 3 a 4 .

Tab. 3 Frekvencia hodnotenia od školských inšpektorov

\begin{tabular}{|l|l|l|l|l|}
\hline $\begin{array}{l}\text { FREKVENCIA } \\
\text { HODNOTENIA / }\end{array}$ & vôbec nie & $\begin{array}{l}\text { menej ako } \\
\text { raz za rok }\end{array}$ & raz za rok & $\begin{array}{l}\text { viackrát ako } \\
\text { raz za rok }\end{array}$ \\
\hline inšpektor & $297(44 \%)$ & $336(50 \%)$ & $32(5 \%)$ & $5(1 \%)$ \\
\hline
\end{tabular}

Tab. 4 Frekvencia spätnej väzby od školských inšpektorov

\begin{tabular}{|l|l|l|l|}
\hline $\begin{array}{l}\text { OBOZNÁMENIE } \\
\text { S VÝSLEDKOM / } \\
\text { HODNOTITEL }\end{array}$ & vždy & niekedy & nikdy \\
\hline inšpektor & $311(46 \%)$ & $47(7 \%)$ & $312(46 \%)$ \\
\hline
\end{tabular}

Hodnotenie riaditel'a je tiež regulované vyššie uvedeným zákonom. Hodnotí ho zriad'ovatel' školy, resp. v prípade, že zriad'ovatel'om je cirkevná inštitúcia Diecézny katechetický úrad. Hodnotenie vykonáva zriad’ovatel' 1x ročne.

Medzi externých, legislatívne ukotvených hodnotitel'ov patrí aj NÚCEM (Národný ústav certifikovaných meraní vzdelávania), ktorý 1. 9. 2008, v rámci nového školského zákona zriadilo MŠVVaŠ SR ako súčast' zmien vo vzdelávacom systéme. Zo zákona by mal NÚCEM hodnotit' učitel'ov raz za rok. NÚCEM ako externá inštitúcia iniciuje internú evaluáciu škôl a komparuje úroveň výchovno-vzdelávacieho procesu na základných a stredných školách. Respondenti z našej ankety uvádzajú NÚCEM ako hodnotitel'a len vel'mi sporadicky.

\section{Inštitucionálne, nepriame hodnotenie:}

\section{a) interné}

Interné hodnotenie tohto druhu realizujú kolegovia $\mathrm{z}$ pedagogického zboru. U začínajúcich učitel'ov je to predovšetkým uvádzajúci učitel' - mentor (Billíková a kol., 2014; Gadušová - Vítečková, 2014; Žilová - Hockicková, 2015; Vítečková a kol. 2016). Potreba uskutočňovat' hodnotenie medzi kolegami vychádza bud' priamo $\mathrm{z}$ radov hodnotených, alebo sprostredkovane, ako návrh na podanie pomocnej ruky zo strany starších kolegov. O hodnotenie a implicitne aj pomoc skúsenejších kolegov spravidla žiadajú začínajúci učitelia $\mathrm{v}$ procese adaptačného vzdelávania. Iniciatíva tohto druhu však môže byt' aj výsledok kritickej sebareflexie u skúsenejších 
pedagógov, ktorí potrebujú radu či usmernenie od svojich didakticky kreatívnejších kolegov. Respondenti z našej ankety uvádzajú tento spôsob hodnotenia vel'mi často. $\mathrm{Na}$ mnohých školách si kolegovia z predmetovej komisie zostavujú harmonogram vzájomných hospitácií. Z hladiska frekvencie sú najčastejšími odpoved’ami ,viackrát za rok“" a „raz za rok“.

\section{b) externé}

Externé hodnotenie sporadicky vykonávajú aj nezávislé, neziskové organizácie $\mathrm{s}$ ciel'om materiálnej pomoci tej ktorej škole. Učitelia $\mathrm{z}$ anketového prieskumu uviedli napr. hodnotenie mentorky organizácie LEAF (Latin Alamitos Foundation Education). K externým hodnotitel'om občas patria, ako vyplynulo z prieskumu, aj kolegovia z iných škôl, ktorí sa viackrát za rok zúčastňujú na otvorených hodinách.

\section{Fakultatívne možnosti hodnotenia:}

Iniciátormi a vykonávatel'mi tohto spôsobu hodnotenia sú rodičia a žiaci. Ak učitel' priamo nepožiada o spätnú väzbu ani jedného z hodnotiacich subjektov, hodnotenie sa realizuje spontánne, s rôznou frekvenciou. Respondenti najčastejšie uvádzajú, že ich žiaci a rodičia hodnotia viackrát ročne.

\section{Autoevaluačné hodnotenie:}

Sebareflexívne hodnotenie je d'alšou neodmyslitel'nou súčast'ou hodnotiacich perspektív. Prieskum potvrdil, že učitelia si uvedomujú jeho dôležitost' a mnohí ho aj využívajú. Sebareflexiu považujú za bezstresovú možnost' autodiagnostiky svojich vedomostí, pedagogických zručností, postojov a pod., ktorá im ponúka bezstresovú korekciu vlastnej pedagogickej činnosti. Predmetom prieskumu však neboli konkrétne metódy sebahodnotenia, preto je otázne, či učitelia chápu tento spôsob evaluácie ako interné zamyslenie sa nad riadením svojho edukačného procesu vodobe sporadických intuitívnych sebareflexívnych otázok, alebo využívajú exaktnejšie sebahodnotiace metódy, prípadne si vedú sebareflexívny denník.

Hodnotitelia všetkých uvedených perspektív majú jeden spoločný ciel: objektívne zmapovanie práce učitel'a alebo svojho vlastného pedagogického pôsobenia. Napriek tomu, že ich spája jednotné úsilie, cesty na dosiahnutie ciel’a sú rôzne. Hodnotenie zahŕn̆a množstvo premenných na strane hodnotitel'a i hodnoteného. Závisí predovšetkým od adekvátneho výberu hodnotiacich kritérií, hodnotiacich nástrojov, formy hodnotenia, spôsobu prezentácie hodnotenia, načasovania a v neposlednom rade aj od osobnostného profilu obidvoch participujúcich strán. V ideálnom prípade je hodnotitel'om kompetentný, pripravený a charakterovo zrelý jedinec a hodnoteným je človek, schopný objektívnej sebareflexie, ktorý prípadnú konštruktívnu kritiku vníma ako nástroj na možnost' kariérneho posunu, a nie ako demotivačný či retardačný prvok. Každé hodnotenie vždy implikuje subjektívny prvok. J. Slavík definuje hodnotenie ako ,proces intelektuálne vysoko náročný, ktorý umožn̆uje človeku na základe subjektívneho (zdôraznili autorky) pristupu rozlišovat'v okolitom svete javy dôležité od nedôležitých a medzi dôležitými javmi odlišovat' javy dobré od zlých. Hodnotenie patri neoddelitel'ne $k$ hodnotám, súvisi s ich uvedomovaním, objavovanim, vyzdvihovaním, pozorovaním alebo spochybřovaním a kritizovaním" (Slavík, 1999 : 22). Subjektívnost' pohl'adu hodnotitel'a na hodnoteného a rovnako ani subjektívnost' reakcie hodnoteného na závery evaluácie nie je možné úplne eliminovat'. Prienik subjektívneho faktora však nie je vjednotlivých hodnotiacich perspektívach identický. Je rozdiel, či učitel'a hodnotí skúsený metodik s rovnakou aprobáciou alebo žiak základnej školy, resp. rodič z celkom inej profesijnej sféry, ktorí jednoznačne nemôžu splnit' kritérium odborne a didakticky kompetentného 
hodnotitel'a. Na druhej strane žiak a jeho zákonní zástupcovi sú, povedané ekonomickou terminológiou, konečnými odberatel'mi učitel'ových výchovnovzdelávacích snáh a nedá sa im upriet' právo na hodnotiace vyjadrenie. V prípade nekompetentného hodnotitel'a - žiaka je potrebné stanovit' presné evaluačné kritéria a hodnotenie realizovat' vo všetkých paralelných triedach, a ak je to možné, v rôznych ročníkoch, v ktorých hodnotený učitel' daný predmet učí. U hodnotitel'a-rodiča (ak má učitel' pocit, že ide o neoprávnenú kritiku) pomôže len vecná a podložená protiargumentácia. U odborne kompetentného hodnotitel'a môže byt' subjektívnost' podmienená predovšetkým osobnostným profilom a individuálnym, pozitívnym či negatívnym postojom $\mathrm{k}$ hodnotenému. V reálnych školských podmienkach neprichádzajú do kontaktu len ideálne konštrukty hodnotitel'a a hodnoteného, tak ako sme ich popísali vyššie, ale l’udia s reálnymi, dobrými i zlými povahovými vlastnost'ami, ktorí sa navyše stretávajú v konkrétnom okamžiku, ovplyvnenom ich aktuálnym fyzickým i psychickým stavom. Svoju úlohu zohráva aj definitórne vágny faktor „l'udského fluida“, ktorý podvedome pôsobí pri osobných kontaktoch. Akceptácia subjektívneho prvku v hodnotení však v žiadnom prípade nesmie narušit' snahu o jeho objektivitu. Naopak. K základným predpokladom hodnotitel'a patrí, aby si subjektivitu uvedomoval, reflektoval ju a výberom vhodných kritérí hodnotenia, argumentačne podloženým zdôvodnením kritických pripomienok a v neposlednom rade i vedome racionálnym prístupom k hodnotenému sa snažil o maximálne potlačenie subjektivity hodnotenia. Zo strany hodnoteného tiež musí íst' o snahu vidiet' veci reálne, nepodliehat' sebaklamu, potlačit' vlastné ego a sebareflexívne zvážit' oprávnenost' kritických pripomienok. Za symptomatickú v tomto kontexte považujeme odpoved' jednej respondentky z nášho prieskumu: „Ono to vlastne závisi od všetkých zúčastnených strán ... v mojej predchádzajúcej škole bolo akékolvvek hodnotenie o absolútnom ponižovaní, nebolo objektívne a ani profesionálne ... dnes som $v$ škole, kde je to presne naopak... zbytočné však nikdy nie je ... človek sa totiž môže poučit' aj z negatívnej skúsenosti ... a nad všetkým hodnotením stoji skutočne $k$ sebe kritická otvorená mysel' učitel'a, ktorého ciel'om by malo byt' neustále sebahodnotenie a snaha o postup vpred... :)“‘.

Od týchto úvah sa odvíja aj pohl'ad hodnotených na psychologický efekt evaluácie. Je potešujúce, že v našom anketovom prieskume považuje $73 \%$ (488 učitel'ov) hodnotenie za motivujúce, 2\% (15 učitel'ov) ho klasifikovalo ako demotivačné, $8 \%$ (54 učitel'ov) ho pokladá za zbytočné a $11 \%$ uviedlo možnost' " iné“. V komentároch v rámci kolónky „iné“ sme zaznamenali celú škálu odpovedí od

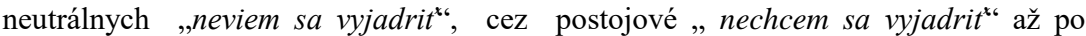
ignorantské „Nechcem mat' názor a hlavne vyjadrit' ho v nejakom dotazniku!!!“. Je zaujímavé, že percentuálne zastúpenie psychologického vplyvu hodnotenia u učitel'ov, vo vel'kej miere korešponduje s vyjadreniami riaditel'ov, z ktorých je 71\% presvedčených, že hodnotenie pôsobí na učitel'ov motivujúco. Ako demotivujúce ho, na rozdiel od hodnotených, neoznačil ani jeden hodnotitel'. Percentuálny podiel, ktorý vyjadruje zbytočnost' hodnotenia je u hodnotitel'ov vyšší (15\%) ako u hodnotených (8\%). Z doplňujúcich komentárov je však zrejmé, že výhrady zo strany riaditel'ov sa týkajú skôr rozsahu a spôsobu hodnotenia (pozri aj Fandelová - Gadušová Lomnický, 2016; Gadušová - Hašková, 2016).

$\mathrm{V}$ prieskume sa učitelia i riaditelia vyjadrovali $\mathrm{k}$ pozitívam i negatívam hodnotenia ako celku. My sme sa odpovede pokúsili kategorizovat', zistit', aké klady a zápory uvádzajú obidve strany v rôznych aspektoch hodnotenia a na ilustráciu uviest' najfrekventovanejšie autentické výpovede reprezentujúce tú ktorú kategóriu.

Pozitíva hodnotenia sme zaradili do štyroch skupín: psychologické, korektívne, komparačné a pragmatické. 


\section{Hodnotený: učitel'}

Kategória Autentická výpoved'

- $\quad$ psychologická: Je to nenahraditelný pocit: "Všimol si ma", aj ked' učitel' nechodi do školy kvôli nadriadeným, ale kvôli detom, žiakom; Hodnotenie môže mat' silný motivujúci charakter, pomáha učitel'om pozriet' sa na svoju prácu z iného pohladu; Pozitívum vidím v motivácii použivania nových foriem a metód vo vyučovacom procese; jednoznačná motivácia $k$ práci na hodine a vškole; Je to motivácia pre osobnostný rozvoj a lepšiu pedagogickú prípravu;

- Korektívna: Učitel' vie zlepšit' výchovno-vzdelávací proces, hodnotiaci ho dokáže upozornit' na chyby, ktoré si on nie vždy dokáže všimnút'; Ak sa vyzdvihnú pozitíva pedagogickej práce učitel'a, vie, že pracuje dobre. Na základe negatívnych informácii sa môže poučit' a odstránit'svoje nedostatky vedukačnom procese; Hodnotenie by malo skvalitňovat' profesijné schopnosti učitel'a. mne osobne pomohlo a pomáha odstránit' nedostatky; Konštruktívna kritika pomáha $k$ zlepšeniu skvalitnenia vyučovacieho procesu;

- komparatívna: Pozitíva vidím $v$ možnosti porovnávania $s$ predchádzajúcimi rokmi; aby sa mohol vrátit’ k tomu, čo mu bolo vytknuté a porovnat' $v$ čom a či sme sa zlepšili;

- $\quad$ pragmatická: Je dôležité pre rast profesionálneho zamerania učitel'a; Potrebné pre vzájomné odovzdanie skúsenosti, postrehov; Objektivizuje pohl'ad na prácu učitel'a $i$ žiakov; $v$ demokratickom vyjadreni svojho názoru; zlepšenie pracovnej atmosféry.

V psychologickej kategórii je dominantnou kvalitou motivačný rozmer hodnotenia. Učitelia uvádzajú motiváciu $\mathrm{v}$ rôznych sférach pedagogickej práce, predovšetkým $\mathrm{v}$ rovine inovácie učebných metód, učebných postupov a profesijného rastu. Oceňujú hodnotenie aj ako dôležitú spätnú väzbu a podnet k sebareflexii. Korektívnu kategóriu tiež zastupuje implicitný motivačný prvok. Rozdiel je však v tom, že tu motivácia nepodporuje len prospektívny rozvoj profesijných kompetencií, ale spätne slúži ako korektív nedostatkov učitel’a. V komparatívnej kategórii vyzdvihujú učitelia možnost' porovnania aktuálneho a predošlého výkonu a zistit' či a aké pokroky urobili. Pragmatickú kategóriu zastupujú výpovede, ktoré za pozitíva hodnotenia považujú individuálny, alebo recipročný prínos, predovšetkým v oblasti odborného rastu, výmeny skúseností, ale aj v zlepšení celkovej pracovnej klímy.

\section{Hodnotiaci: vedenie školy}

Kategória Autentická výpoved'

- $\quad$ psychologická: Konštruktívny dialóg, vzájomná diskusia posúva učitel’a d'alej, motivuje ho...; Dobré rady pôsobia vždy inšpirujúco na hodnoteného pedagóga; Má motivačný účinok pre pedagogického. zamestnanca, aby mohol "modelovat" svoju vlastnú profesijnú cestu; Pomôže pri stanovení konkrétnych ciel'ov a úloh, podporuje aj osobnostný rozvoj učitel'a;

- Korektívna: Hodnotenie ukazuje na to, čo je potrebné urobit' na zlepšenie činnosti učitel'ov a ich pracovného výkonu, aby boli naplnené hodnoty a ciele školy; Aby bolo hodnotenie úspešné, musi hodnotený poznat' svoje nedostatky, vyjadrit' sa $k$ nim, aby do budúcna vedel svoje nedostatky napravit; Hodnotenie spojené so sebahodnotením vedie učitel'ov $k$ tomu,

Slavonic Pedagogical Studies Journal, ISSN 1339-8660, Volume 6 Issue 1, February 2017 
aby sami sledovali a hodnotili svoj pracovný výkon a menili jeho kvalitu prostrednictvom kontinuálneho. vzdelávania. a sebavzdelávania; . Hodnotiace rozhovory aktualizujú ciele a plány školy, riešia problémy výkonu učitel'ov. Ide o monitorovanie výkonu vo vzt’ahu $k$ profesijným štandardom, poskytovanie spätnej väzby na zmenu kvality kompetencii učitel'ov;

- Komparatívna: Je to potrebné, považujem ho za istú formu porovnania a výmeny skúseností; Porovnanie názoru vedenia školy a žiakov na učitel’ov vedie $k$ sebareflexivnemu porovnaniu, ako sa vidi učitel', ako ho vidí hodnotiaci a ako ho vidia žiaci.

- $\quad$ pragmatická: Hodnotenie je súčast' života, nie je možné sa mu vyhnút', preto je nutné prijat' hodnotenie ako pozitívnu stránku života.; Je vel’mi dôležité a budem v ňom pokračovat' aj ked' nebude povinné; Je to dôležitá personálna činnost', ktorá pomáha zamestnávatel'ovi zistit', akých schopných a výkonných zamestnancov má, ako prispievajú $k$ výsledkom školy; Je to dobrá vec, ktorá sa využiva pri určeni odmien; Je to ukazovatel' kvality školy, súčast' TQM komplexného manažmentu školy, zvyšovanie kvality vyučovacieho procesu od plánovania činnosti učitel'a, cez realizáciu, po hodnotenie vlastnej činnosti.

V psychologickej, korektívnej a komparačnej kategórii uvádzajú hodnotitelia (riaditelia škôl) v podstate identické pozitíva a funkcie hodnotenia ako učitelia. V pragmatickej kategórii zdôrazňujú selektívnu funkciu hodnotenia, ktorá sa stáva meradlom výkonnosti pedagogického zboru, kvality školy a kritériom na finančné ocenenie učitel'a.

\begin{tabular}{|lc|}
\hline Negatíva & Učitelia \\
\hline Kategória & Autentická výpoved' \\
\hline
\end{tabular}

- psychologická: Pre mňa osobne je to vel'mi stresujúca záležitost', mám pocit, že každá vyučovacia hodina je pre učitel’a zároven̆ aj hodnotením aj inšpekciou našimi žiakmi, ktorých uč́m.; Učitelia majú vždy z hodnotenia obavy; Mám stres z rozhovoru s hodnotitel'om, pocit, že sa zameria na negatívne stránky učitel'a; Mám strach z neúspechu; mám trému, až strach pred hodnotením; Pre mňa strach a stres a zakaždým mám pocit, že všetko, čo robím je zlé; Málo si verím a pritom mám túto prácu vel'mi rada; Učitel' nie vždy v strese podá najlepši výkon, taktiež žiaci sú vtedy stresovani a nevyvíjajú takú aktivitu ako počas bežnej hodiny; Môže skĺznut' do negatívneho postoja, ak sa vytvára napätie vo vzt'ahu riaditel' - učitel', a to je stresujúce; Niekedy sa človek bojí oponovat' nadriadenému; Preceňovanie subjektivizmu, orientácia pozornosti na výkon, čím vyvija na zamestnanca väčsi tlak; Cítim sa ako v škole :) Neviem, či sú hospitácie potrebné $v$ takej vysokej miere, ale niekedy z nich mám stres. Negativne hodnotenie vnímam ako zbytočné, môže viest' $k$ vyhoreniu učitel'a. Netaktným hodnotením môže byt' hodnotený učitel' frustrovaný a demotivovaný; Kritika (neoprávnená, prílišná) zo strany hodnotitel’a môže odradit', zneistit' najmä začinajúcich učitel'ov.

- $\quad$ etická: Subjektívny názor hodnotitel'a; Hodnotiaci často vypracuje písomné vyjadrenie bez rozhovoru a vyjadrenia hodnoteného; Zaujatost' nadriadeného a vnútorné emócie; Neobjektívne (občas unáhlené) závery; Neobjektivne, podla vopred zadanej schémy; $V$ diskusii s nadriadenými t’ahá učitel' za kratšie nitky; Neobjektívny hodnotitel' môže vydat' zlé, nereálne hodnotenie; Negatíva vidím v nebezpečenstve zneužitia postavenia hodnotitel'a voči učitelovi; Presadzovanie vlastných názorov, 
neakceptovanie názorov najmä mladých začinajúcich učitel'ov; Je potrebné hodnotit' primeranou formou, aby to nemalo charakter šikanovania; Je mimoriadne neobjektivne ohodnotit' prácu pedagóga na základe niekol'kých hospitácií v triede počas roka. Hodnotenie učitel'ov je väčsinou realizované hospitáciou na 1 vyučovacej hodine, na 1 hodine sa nedá komplexne a objektivne zhodnotit' práca učitel'a (využivané metódy a formy práce, využivanie pomôcok, IKT...); Často býva subjektívne s cielom "nájst'za každú cenu chyby", je formálne, nie je zamerané na pomoc učitelovi; Často je neobjektivne, vedenie školy dá za pravdu rodičom, tí chcú iba dobré známky; Problém môže nastat', ak hodnotitel' nie je prístupný a ochotný diskutovat' a správa sa despoticky, direktívne; Myslím si, že každý pedagóg, ked’že svoj odbor vyštudoval, je odbornikom vo svojej aprobácií. Hodnotenie ovládania obsahu učiva nepovažujem za korektné;

- realizačná: Hodina, na ktorej je hodnotitel', je niekedy "umelo vytvorená" ( $v$ zmysle, žiaci sa správajú inak); Hovorí sa, že kto robí, robi aj chyby, ak učite na hospitovanej hodine tak, ako vždy na každej hodine a neštylizujete sa do nejakých "póz" a "ukážkových hodin", tak ste hodnotený priemerne...a pod. Ak niekto urobi ukážkovú hodinu, na ktorú sa so žiakmi pripravuje, je hodnotený výborne...:(a čo uči d'alšie hodiny už nie je také podstatné..), toto mi na spôsobe hodnotenia prekáža ...; Skreslujúci výsledok v prípade nesplnenia ciel'ov hodiny a následné zaškatul'kovanie učitel'a; Hodnotenia sú založené na analýze dotazníkov, ktoré sú zadané žiakom a žiaci nie vždy chápu otázky. Preto sú výsledky v triedach rôzne. Č́m starši žiaci, tým lepšie hodnotenie; Hodnotenie je skreslujúce, pretože dotazniky sa dávajú len v niektorých triedach; Hodnotia sa aspekty, ktoré podla mn̆a nie sú skutočne dôležité pre vyučovanie a výchovu detí; Niekedy sa hodnotenie zameriava len na jednu stránku vyučovacieho procesu, napr. kontrola splnenia ciel'a, či sa uplatnil diferencovaný prístup a nehodnotí sa efektivita využitých metód; Negatívum vidím v zasahovaní do vyučovacieho procesu učitel'a s dlhoročnými skúsenost'ami, ktorý nepotrebuje hodnotenie od druhých;

- $\quad$ kompetenčná: Často hodnotiaci nie je kompetentný v odbore (zástupkyňa), vtedy sa zameriava striktne na splnenie plánu a nie na potreby žiakov; Rozdielnost' aprobácii a s tým súvisiace priority vo výchovnovzdelávacom procese; Občas vidím nekompetentnost' hodnotitel'a... zvlášt', ak hodnotený a hodnotitel' majú odlišné aprobácie a riešia napr. ovládanie obsahu vyučovacieho predmetu učitel'om a ovládanie učiva predmetu žiakmi; Nehodnotí ma "profesionálny didaktik, metodik"; inšpektor nie je odbornik, nemá ani minimálnu skúsenost's prácou v teréne, nevie poradit', zaujímajú ho len papiere; Pokial' učitel'a hodnotí nadriadený, je to v poriadku, lebo pozná jeho prácu, čiže môže hodnotit' objektívne. Inšpektor však nedokáže objektívne posúdit' prácu učitel'a z 1 alebo 2 hospitačných hodín...; Na hodnotenie inšpektorov si neviem vytvorit jasný názor...je jasné, že aj takýto hodnotiaci nástroj musi existovat', ale niekedy pochybujem o ich kompetenciách ........celý ich hodnotiaci systém je nejaký pomýlený a nereflektuje na prax.....prax, ktorú zaživame na školách. Nech ma zhodnotí ten, čo pozná moju prácu, nie dáky metodik od stola ......čo videl deti naposledy v r.1988 na obrázku; Ak sú inšpektori na škole mám pocit, že u nich prevláda iba teória a žiadna prax. Sú dobri vo svojom odbore „, inšpektorovat"“, ale ked' majú nejaké výhrady tak nech sa postavia pred žiakov a nech nám ukážu ako máme učit; Hodnotenie učitel'ov kolegami, ak je také, že napomáha riešit' problémové situácie, tak OK. Hodnotenie 
učitel'ov rodičmi je neobjektívne a nekompetentné; Nás už hodnotí ktokol'vek ...; Mnohé hodnotenia učitel'ov médiami sú zavádzajúce, trápne, vyvolávajúce spory, hanlivé, jednoducho, učitel' sa musí naučit' ignorovat' mediálnych "vševedov";

- $\quad$ pragmatická: ... i to najlepšie ohodnotenie učitel’a mu neprináša adekvátne finančné ohodnotenie; ...nie všetci si plnia svoje povinnosti, práca má byt' aj adekvátne ocenená, kto pracuje a dosahuje aj vynikajúce výsledky - má byt ohodnotený; Ohodnotenie. ... aj napriek väčšiemu množstvu vol'na, nezodpovedá vykonanej práci. Ani patológ, ani lekár alebo automechanik si prácu domov nenosí, ale učitel' často krát musí. Nehovoriac o tom, že žiakov nielen vzdelávame, ale aj vychovávame, čiže do značnej miery ovplyvňujeme ich budúcnost'; Myslím si, že hodnotenie učitel'a v našej krajine je len formálne a nie dost' efektívne, vedie $k$ byrokratizácii; Je to administrativna zátaž pre učitel'a; Samotná pedagogická profesia je málo zaujímavá, učitelia nie sú dostatočne vnútorne motivovaní; Zbytočne budeme prácu učitel'a hodnotit', ak jej výsledky nedokážeme žiadnym spôsobom ocenit', celý výchovno-vzdelávací systém žiada motiváciu žiaka, ale učitela iba demotivuje a $v$ súčasnosti aj demoralizuje; Školám chýbajú kritéria hodnotenia. Okrem toho, učitelia na Slovensku sú nedostatočne pripravovani na svoju profesiu, čo sa odráža na kvalite práce. Úspešný pedagóg sa snaži vzdelávat', aby mohol byt' čo najnápomocnejši žiakom. Vnútorne motivovaný učitel' nepotrebuje vonkajšie formálne ohodnotenie. Je to skôr potreba školy na dosahovanie svojich cielov.

V psychologickej rovine vnímajú učitelia vel'mi často hodnotenie ako stresový faktor. $\mathrm{V}$ primeranej miere je strach $\mathrm{z}$ hospitácie, resp. $\mathrm{z}$ rozhovoru s nadriadeným, $\mathrm{v}$ zmysle konfrontácie s neznámou sociálnou situáciou prirodzený a pocituje ho každý z nás. Nežiaduca je však vyššia miera strachu, ktorá môže prerást' do tzv. anticipačného stresu a ten už negatívne ovplyvňuje pracovný výkon. Individuálne osobnostné charakteristiky učitel'a (introverzia, nedostatok sebadôvery, znížené sebavedomie, neistota, úzkost'), ale aj perfekcionizmus môžu byt' istou predispozíciou k vzniku neadekvátnych pocitov úzkosti. Príčinou však často nie sú endogénne, ale exogénne faktory. Tie spravidla súvisia s povahovými vlastnost'ami hodnotitel'a (prehnane autoritatívny prístup, nedostatok empatie, netaktnost' podania kritiky a pod.). Učitel'ské povolanie inheruje prácu i kontakt s l'ud'mi rôznych vekových kategórií a vo vel'kej miere aj závislost' na ich hodnotení - tento fakt už sám o sebe pôsobí ako stresor. Navyše je spojené s vel'kou zodpovednost'ou, vyžaduje si nemalé pracovné nasadenie, často sa pri ňom nehovorí o povolaní, ale o poslaní. Dlhotrvajúca psychická zát’až, tlak na výkon, nehmotné i finančné nedocenenie vedie čoraz častejšie k disharmónii medzi profesijnými očakávaniami učitel’a a školskou realitou. Odtial' je už len krok k psychickému vyčerpaniu, strate motivácie, profesionálneho záujmu, $\mathrm{k}$ frustrácii a napokon $\mathrm{k}$ syndrómu vyhorenia, ktorý je $\mathrm{v}$ učitel'skom povolaní reálnou hrozbou. Je preto vel'mi dôležité, aby hodnotený i hodnotiaci disponovali adekvátnymi sociálnymi kompetenciami a v procese evaluácie dokázali viest' vzájomne korektný a konštruktívny dialóg. V etickej kategórii vyjadrili učitelia celkom legitímnu požiadavku maximálnej objektivity. Tá úzko súvisí $\mathrm{s}$ profesionálnym prístupom $\mathrm{k}$ hodnotitel'ovi bez osobných animozít a neúmerného presadzovania vlastného ega. Implicitne zaznela aj akútna potreba neformálnych hodnotiacich kriterií a nutnost' kontinuálneho hodnotenia, bez prenáhlených záverov z jednej hospitovanej hodiny. Ostatne uvedená požiadavka naplno rezonuje v realizačnej kategórii. Na požiadavku objektivity bezprostredne nadväzujú aj kritické výhrady k reprezentantom niektorých hodnotiacich perspektív, ktoré učitelia uviedli v kompetenčnej kategórii. Vhl'adáčiku kritických pripomienok boli 
predovšetkým školskí inšpektori a rodičia. Napriek tomu, že v jednotlivých vyjadreniach (a nebolo ich málo) explicitne zaznel výraz „nekompetentný“, myslíme si, že - prinajmenšom $v$ prípade inšpektorov - nejde o spochybňovanie hodnotiacej spôsobilosti ako takej, ale skôr o strach z neobjektivity záverov z jednorazových hospitácií. Pocit (a často aj fakt), že inšpektor nepozná klímu školy, triedy, priebežný výkon učitel'a, ani žiakov a je z externého, mimoškolského prostredia, vytvára „nadstavbový“ stresor, ktorý zvyšuje obavy a vedie k obranným reakciám, typu: „Nemáš právo kritizovat, kým si to nedokázal sám“. Perspektíva rodiča ako hodnotitel'a je najproblematickejšia. Kým žiak je aspoň priamym účastníkom edukačného procesu, rodič je len hovorcom (často skreslených) informácii z druhej ruky. Zatial' čo pri oficiálnom hodnotení žiakov existujú konkrétne hodnotiace kritéria, ktoré evaluáciu aspoň čiastočne objektivizujú, rodič nemá k dispozícii žiaden reliabilný hodnotiaci nástroj. Pri neoprávnenej kritike učitel’a zo strany rodičov má učitel' v rukách jedinú pomyselnú zbraň - presvedčivú argumentáciu. V pragmatickej rovine sa kritické pripomienky učitel'ov týkajú dvoch oblastí: už klasického problému finančného podhodnotenia učitel'skej práce a naliehavého problému absencie zodpovedajúcich hodnotiacich štandárd.

\begin{tabular}{|lc|}
\hline Negatíva & Riaditelia \\
\hline Kategória & Autentická výpoved' \\
\hline
\end{tabular}

- $\quad$ psychologická: Nie každý učitel' vie prijat' konštruktívnu kritiku; Sú to citlivé témy a úlohu zohráva aj vekový rozdiel; Negativum môže byt' aj nepochopenie situácie, neobhájenie vlastného názoru; Vyjadrenie len z pozície nadriadený a podriadený. Konštatačný pohl'ad jednej strany. Prehlbuje sa nedôvera a neochota spolupráce a začína neistota robím to dobre, mám niekde rezervy, čo môžem ešte ponúknut? atd’....; V prípade nie príliš pozitívneho hodnotenia niektorých kolegov dochádza niekedy $k$ emotívnej diskusii; Stres učitel'a, hodnotitel' vyzerá ako sudca, aj ked' to tak nie je, nechávam priestor učitel'ovi, aby sa ohodnotil, ale on to možno tak nepocituje; Negatívum by bolo to autoritativne vystupovanie vedenia školy navodzuje negatívnu klímu v škole a brzdi aktivitu učitelov; Niekedy je problém vyjadrit' svoj názor z pohl'adu učitel'ov, a často si hodnotenie berú ako osobný útok na svoju osobu;

- etická: Negatíva vidím v neobjektívnom hodnotení; Často dominuje formalizmus.; Môže dôjst' $k$ subjektívnemu prístupu hodnotitel'a alebo hodnoteného.; Ročné hodnotenie môže byt' aj nepravdivé, je dost' riaditel'ov, ktorí si týmto "vybavujú účty" s podriadenými. Za neetické považujem obhajovanie nesplnených úloh zo strany učitel'ov; Zbytočné, neodzrkadluje skutočné kvality, prednosti učitel'a.; Byrokracia - všetko vypisovat', zakladat', archivovat'...vedenie školy $v$ dôsledku byrokracie kopíruje $z$ predchádzajúceho šk. roka.; Nakol'ko hodnoti nadriadený je to subjektivny pohl'ad 1 osoby, ktorý nemusí byt' totožný s prístupom $k$ učeniu hodnoteného PZ.; Stále hodnotenie vnímam ako dvojsečnú zbran̆. V mnohých pripadoch sa robi len kvôli povinnosti zo zákona. Momentálne ho považujem za neefektivne a zbytočné;

- realizačná: Hodnotenie, ako spätná väzba mojej práce je potrebná. Nemalo by sa to však zužovat' na hodnotenie osoby, ale na priebeh a výsledky práce danej osoby - teda odosobnit' proces hodnotenia. Ak by ho takto vnímali obidve strany, hodnotenie by prospelo obom stranám, ale najmä tým, o ktorých v celom výchovno-vzdelávacom procese ide - teda detom. Lebo na jeho konci by bol lepši pedagóg a žiak, ktorý sa teši do školy.; Je problém ziskat' objektivny obraz úrovne práce učitel'a. Činnost' počas hospitácií je 
iná ako pri neúčasti vedenia školy; Každý riaditel' si pozná svojich učitelov a vie ich hodnotit' $i$ bez toho, aby vypisoval množstvo papierov, ako to vyžaduje Zákon 317/2009 Z.Z a školská inšpekcia. Riaditel' má byt' otcom školy a nie byrokratom;

- $\quad$ pragmatická Dlhšie trvajúca príprava na hodnotenie a tiež samotný priebeh hodnotenia; Nedostatok času na dôsledné hodnotenie, riaditel' je "zavalený" tolkými povinnost'ami pri zabezpečeni chodu školy, dopíñaní materiálno technických. podmienok školy (ktoré by mal automaticky zabezpečit' štát!), že má málo času venovat' sa tomu, čo je v škole najpodstatnejšie - edukácii.; Formálne učitel' je najlepšie hodnotený na výplatnej páske. Hodnotenie učitel'ov by malo korešpondovat's pohyblivou zložkou platu; Administratívne zat'ažujúce, neefektívne, nedostatočne stimulujúce. A keby sme to všetko chceli hodnotit', nie formálne, ale objektivne, premyslene, otázka znie, kedy.

Riaditelia škôl uvádzajú v psychologickej kategórii vpodstate dva druhy neprimeraných reakcií učitel’ov na hodnotenie. Jedna vzniká v konfrontácii nadriadeného s podriadeným a navonok sa prejavuje formou prehnanej emotívnosti, vzt'ahovačnosti, pocitu krivdy, neschopnosti prijat' konštruktívnu kritiku. Druhá vyplýva skôr z konfrontácie hodnoteného s novou sociálnou situáciou, resp. so sebou samým a jej výsledkom je strach alebo neschopnost' využit' ponúkaný priestor na vyjadrenie či obhajobu vlastného názoru, prípadne nesprávne vyhodnotenie situácie a subjektívny pocit ohrozenia bez objektívneho dôvodu. Je zaujímavé, že v etickej kategórii aj riaditelia pripúšt’ajú neobjektívnost' hodnotenia, niekedy dokonca vyúst’ujúcu do vybavovania si účtov s podriadeným. Závažným problémom je formálnost' hodnotenia, ktoré sa robí len preto, že ho diktuje zákon. Je alarmujúce, že vo výpovediach učitel'ov i riaditel'ov sa objavuje kritika neetického prístupu $\mathrm{k}$ hodnoteniu, ked' sa jeho závery $\mathrm{z}$ jedného roka jednoducho prekopírujú a $\mathrm{v}$ d’alších rokoch sa vydávajú za aktuálne hodnotenia. Za iritujúcu považujú riaditelia situáciu, ked' sa učitelia snažia prázdnymi výhovorkami obhájit' neobhájitel'né, napr. lajdáckost' a neplnenie úloh. V realizačnej kategórii sa riaditelia i učitelia zhodujú v tom, že sporadické hospitácie, ktoré sú vždy poznačené zvýšeným stresom a istou štylizáciou, nemajú takú výpovednú hodnotu, aby sa z nich dali vyvodit' jednoznačné závery o kompetentnosti či nekompetentnosti učitel'a. Viackrát zaznela aj požiadavka depersonalizácie hodnotenia, t. j. vzájomného pochopenia, že ide o „vec" a nie o „osobu“ hodnoteného či hodnotiaceho. V kompetenčnej kategórii sme zo strany riaditel'ov nezaznamenali žiadnu kritickú pripomienku, preto ju pri kategorizácii riaditel'ov neuvádzame. $\mathrm{V}$ pragmatickej kategórii riaditel’ov najviac trápi administratívne zat’aženie spojené s hodnotením, nedostatok času na neformálnu evaluáciu kvôli narastajúcej byrokracii spojenej tak s legislatívne zakotvenou povinnost'ou hodnotit' učitel'a, ako aj s celkovým zabezpečením chodu školy.

Zmapovanie pozitív i negatív hodnotenia $\mathrm{z}$ aspektu hodnotitel'ov i hodnotených poskytuje relatívne komplexný obraz o názorovej hladine učitel'ov a riaditel'ov na evaluáciu ako významný nástroj personálnej práce. Na druhej strane vytvára tento obraz východiskovú platformu pre opatrenia, ktoré by aspoň čiastočne dokázali eliminovat' najzávažnejšie nedostatky hodnotenia, uvádzané vo výpovediach obidvoch subjektov evaluácie. Náš príspevok má ambíciu načrtnút' niektoré z týchto opatrení.

Z hl'adiska objektivity a etickej dimenzie hodnotenia považujeme za potrebné: 
- akútnu potrebu vytvorenia (a hlavne reálneho využívania) všeobecne platných profesijných štandárd, ktoré by špecifikovali základné kompetencie a reprezentovali učitel'skú profesiu ako takú. Jednoducho povedané, kompetencie, bez ktorých učitel' nemôže naplnit' status tohto povolania a ktoré by hodnotenie objektivizovali bez ohl'adu na hodnotiace perspektívy.

- nutnost' vytvorenia diferencovaných kritérií, resp. subkritérií podla konkrétnych podmienok školy. Napr. pri hodnotení podl'a výsledkov žiakov, rozdielne hodnotit' učitel'a, ktorý pracuje $\mathrm{s}$ tzv. štandardným žiackym kolektívom a učitel'a, kde zloženie triedy predikuje horšie výsledky (žiaci zo sociálne znevýhodneného prostredia), diferencovane hodnotit' učitel'a v oblasti využívania učebných pomôcok a ITK pri adekvátnom a neadekvátnom materiálno-technickom zabezpečení školy;

- V záujme objektivity hodnotenia pri celkovej evaluácii zabezpečit' hodnotenie z viacerých interných, prípadne aj externých perspektív. Tým sa zároveň relativizuje - zo strany učitel'ov i riaditel'ov tak často kritizovaná unáhlenost' záverov jednorazových hospitácií a aspoň čiastočne sa dosiahne tzv. intersubjektívna spol'ahlivost' hodnotenia;

- posilnit' a priorizovat' osobné kompetencie (rozvíjat' empatiu, schopnost' adekvátne prejavovat' a zvládat' emócie, uvedomovat' si a reflektovat' vlastnú subjektivitu, prijímat' konštruktívnu kritiku), sociálne kompetencie (posilňovat' pocit spolupatričnosti, žičlivosti a tímovej práce $\mathrm{v}$ prospech školy, schopnost' kooperatívneho a vecného riešenia konfliktov) a komunikačné kompetencie (schopnost' viest' podnetný dialóg, naučit' sa kriticky vyjadrovat' a prijímat' kritiku primeranými verbálnymi i neverbálnymi prostriedkami), a to u každého učitel'a a učitel'a vo vedúcej funkcii zvlášt'. Vytvorit' funkčné hodnotiace kritéria na evaluáciu tohto súboru kompetencií, aby sa učitelia necítili byt' frustrovaní nevhodnou dikciou kritiky a riaditelia škôl nestáli pred rovnakou dilemou, ako jeden $\mathrm{z}$ našich respondentov: Mala by sa hodnotit' nielen kvalita učitel'a, ale aj jeho hodnoty a správanie voči žiakom, rodičom, aj kolegom. Čo s učitel'om, ktorý má problémy komunikovat's rodičmi, narúša medziludské vzt’ahy a pod.? Aj toto sú l'udské vlastnosti, hodnotením sa nezmenia...;

- vytvorit' nový efektívny sebahodnotiaci formulár, resp. rozšírit' sebareflexívne portfólio učitel'a o čast', ,individuálne zlepšenie“, kde by si každý učitel' sám, podl'a individuálnych nedostatkov vytýčil 1-2 interné ciele na zlepšenie tých kompetencií, v ktorých pocit'uje najväčšie slabé miesta a snažil sa ich odstránit'. Pri d’alšom zápise by zhodnotil, či a nakol'ko sa mu ich podarilo eliminovat' a postupne by si stanovoval nové ciele. Bezstresová interná autodiagnostika by mu pomohla vytvorit' si objektívnejší obraz o svojej práci a hlavne by získal aj spätnú väzbu o vlastných pedagogických pokrokoch;

- vytvorit' paralelnú, alebo aj hierarchizovanú postupnost' hodnotenia začínajúcich učitel'ov (permanentné sebareflexívne hodnotenie efektívnymi hodnotiacimi nástrojmi, hodnotenie kolegami s rovnakou aprobáciou, pravidelné hodnotenie žiakmi podl'a zrozumitel'ných a presných kritérií, hodnotenie mentora, hodnotenie vedením školy, hodnotenie $\mathrm{z}$ externého prostredia). Touto postupnost'ou, predovšetkým posilnením sebareflexívnej zložky a priatel'skej rady kolegov by si začínajúci učitelia postupne budovali profesijné sebavedomie. Hodnotenie žiakmi považujeme za dôležitú súčast' celkového hodnotenia, ale na druhej strane každý učitel' musí vziat' do úvahy, že motívy a interné postoje žiakov pri hodnotení 
nemusia vždy reflektovat' jeho objektívne pedagogické kvality. Aj v tejto profesii platí okrídlený výrok „každému nevyhovieš“. Rovnako málo exaktné, ale relatívne objektívne je kritérium: Ak je z početnej triedy nespokojný jeden či dvaja žiaci, ide o subjektívne reakcie, ak je nespokojná väčšina žiakov, musí sa nad svojím pedagogickým pôsobením zamysliet' učitel'.

Záverom nášho príspevku by sme opätovne chceli zdôraznit' nevyhnutnost' a motivačný potenciál hodnotenia, čo si uvedomujú hodnotení i hodnotiaci. Je však nesmierne dôležité, aby bolo čo najobjektívnejšie, najneformálnejšie, a aby sa z neho nevytratil empatický l'udský rozmer. Vel'mi výstižne to vyjadril jeden z našich respondentov z radov riaditel'ov: "Hodnotit' treba, ale človečenstvo je prvoradé".

\section{Bibliographic references}

BILLIKOVA, A. et al. 2014. Key competencies of mentor teachers essential for successful mentoring of novice teachers: A research study, 2014. In: XLinguae, vol. 7, n. 4, pp. 55-74. ISSN 1337-8384

FANDELOVA, E. et al. 2016. Head Teacher's Perception of Teacher's Oral and Written Assessment. In: Efficiency and Responsibility in Education 2016. Praha: Czech University of Life Sciences, CD-ROM, pp. 113-120. ISBN 978-80-213-2646-0 GADUŠOVÁ, Z. - HAŠKOVÁ, A. 2015. Training Educational Staff: Vision and Reality in Pre-service and In-service Training. In: EDULEARN15, Barcelona: IATED, 2015, pp. 2046-2053. ISSN 2340-1117

GADUSOVA, Z. - HASKOVA, A. 2016. Evaluation of Teachers' Competences as a Part of School Leadership. In: Communication, Business and Education 2016. Singapore: Singapore Management and Sports Science Institute, pp. 7-12. ISSN 22513051

GADUSOVA, Z. et al. 2016. Evaluation of Teachers' Competences. In: INTED 2016 Valencia: IATED Academy, CD-ROM, pp. 6957 - 6965. ISBN 978-84-608-5617-7

GADUSOVA, Z. - VITECKOVA, M. 2014. Teachers Professional Induction in the Czech Republic and Slovakia. In: American Journal of Educational Research, vol. 2, n. 12 (2014), pp. 1131-1137. ISSN 2327-6126

GADUSOVA, Z. - VITECKOVA, M. 2015. Transition of novice teachers into school teaching and their support by mentor teachers. In: ATEE 2014: Transitions in teacher education and professional identities, Braga: University of Minho, pp. 411-420. ISBN 9789081563987

KRALOVA, Z. - SORADOVA, D. 2015. Foreign language learning anxiety. In: Teaching Foreign Languages to Learners with Special Educational Needs : e-textbook for foreign language teachers. Nitra: UKF, 2015. ISBN 978-80-558-0941-0, CDROM, s. 91-100

MAGOVA, L. 2016. Hodnotenie kompetencii ucitelov v europskom a slovenskom kontexte. Praha: Verbum. ISBN 978-80-87800-28-7

POLOK, K. 2009. When Teaching Matters... A Collection of Papers on Linguistics, Language Education, and Classroom Dynamics. Bloomington: Author House. ISBN 978-1-4389-3519-5

RAFAJLOVICOVA, R. - STULRAJTEROVA M. 2002. Skusanie, testovanie a hodnotenie v edukacnom procese. Bratislava: Statny pedagogicky ustav. ISBN 8085756-67-6

SLAVIK, J. 1999. Hodnoceni v soucasne skole. Vychodiska a nove metody pro praxi. Praha: Portal. ISBN 80-7178-262-9

TUREK, I. 2008. Didaktika. Bratislava: Iura Edition. ISBN 978-80-8078-198-9 
VÍTECKOVA, M. et al. 2016. Teacher at the Start of his Career and his Personal Needs. In: Efficiency and Responsibility in Education 2016, Praha: Czech University of Life Sciences, CD-ROM, pp. 624-633. ISBN 978-80-213-2646-0

VYHLASKA Ministerstva školstva SR z 31.3.2005.

ZAKON č. 317/2009 o pedagogickych zamestnancoch a odbornych zamestnancoch.

ZAKON č. 596/2003 o statnej sprave v skolstve a skolskej samosprave.

ZILOVA, R., HOCKICKOVA, B. 2015. Secondary School Mentor Training in Slovakia. In: ERIES Journal, vol. 8, issue 3, pp. 60-66. ISSN 2336-2375

Táto práca bola podporovaná Agentúrou na podporu výskumu a vývoja na základe zmluvy č. APVV-14-0446.

prof. PhDr. Eva Malá, CSc.

prof. PhDr. Daniela Müglová, CSc.

Department of Translatology

Department of Language Pedagogy and Intercultural Studies

Constantine the Philosopher University in Nitra

Tr. A. Hlinku 1, 94901 Nitra

Slovenská republika

dmuglova@ukf.sk

emala@ukf.sk 